\title{
Gypsy Identity
}

\section{Jorge Emilio Nedich}

jen050259@gmail.com

Born in 1959 in Argentina in a nomad Ludar family, Nedich did not receive any formal education until 1999, when he was granted the right to be admitted to the B.A. program at the Universidad Nacional de las Lomas de Zamora. A writer, editor, and teacher, he has published fourteen books, being twice a finalist for the prestigious Planeta Prize. In 2014 he published his last novel, El alma de los parias, which was well received both by critics and readership. His work has been translated into several languages. "Gypsy Identity" is the first chapter from an unpublished novel, La transformación interminable (The neverending transformation). 
My father and I walked hand in hand, dilly-dally, as two who dearly love each other. From time to time we let go, laughing as we ran and kicked the dirt clumps under our feet, but only those that rose, sassy and filled with air, bursting as soon as we hit them. We also looked for four-leaf clovers, plucking them and placing them behind our ears; not too many, just enough to get lucky and avoid misfortune. We were still laughing when a storm suddenly broke, as if a river flooded from the sky. My father turned around and looked at my mother, who followed behind. He shrugged helplessly, raised his head and looked up. He must've seen something up there, in the sky, or maybe God said something bad about premature babies, because he was upset as he looked down.

He placed his hands on his waist, looked up to the sky again, spit and exclaimed, “Goddamn it!"

My mother stared at him and replied, "Your damn mouth."

Then, my father made a promise to himself, "I will go to Mr. Patarino's house, knock on the door, and request to borrow one, just one mule to attach to the wagon so we can continue our journey. If I look decent, he will lend it to me, otherwise, God have mercy on us."

"What do you think you are doing?" my mother asked him defiantly. "You are going to ruin your suit in this rain."

"Yes, what am I doing?" he said as he gave me his hat. He removed his jacket and trousers, folded them carefully, piled one on top of the other, like husband and wife, and placed them under his arm so the rain would not damage them. With his clothing safeguarded, he walked towards the house, which was not far but could not be seen in the heavy rain.

As he passed by naked, my mother asked, "Don't you have any underwear?"

"I don't have a mule," he replied, putting on the hat that I had just handed him.

My father came back sad.

"We'll get one somehow," my mother told him.

And that is all that I remember. I mean from the last day when my dad was still alive. From my father's death I got the sadness of being in the rain, which grew deeper inside me when my mother, during his wake, led on a loser that was good for nothing.

That night I cried for a long time after my mother said, "Petre, we are on our own now, and I have to think about you and me. That guy promised to bring us a mule."

I did not like the mule he brought, even though it did pull the wagon. It made me sad to look at it because its stride was not gypsy, not like a stride my dad's mule would have. Not even close.

And then my mother said to me, "Wipe that look off your face and be grateful because, even if your father had managed to get a mule, he might still have died. He was sick, don't you forget that."

"That's right," said the wino, and sat me by his side.

I did not want to, but I stayed put because my mom smiled at me.

Next day, in the carriage, he handed me the reins, and I liked that. But after a while I stopped looking ahead and watched the mule's tail instead, following the flies, swiping at them now and again. The wino got mad because the wagon went off the road, and he scolded me.

"Give me those reins, you premature boy."

I looked at my mother just to check if she had heard, just for that, but she seemed not to pay attention. She just hit me in a way that did not hurt because I understood what she meant. 
I moved to the back, slurped my snot, and watched how the road slipped away from the wagon.

Later on, and for whatever reason, my mom also got hit and came back with a hand on her nose, wiggling it and sniffling. She sat by my side and watched the road moving away. I did not want to join her, so I started to think about my father. I could see him drenched under the rain, with his T-shirt down, covering his bum. But his thing was hanging down, like a dog's. I saw my mother thinking as well. I was not quite sure, but it seemed to me that she was often lost in her thoughts.

The wino noticed as well because he shouted, "Don't waste your time, you already did it when you gave birth to that thing." And he pointed at me. He talked about me all the time, but he hardly knew me.

I asked my mother once, "Take me to grandpa."

She shook me and screamed, "Shut up, you premature boy."

One morning my mother went to the neighbours to help some kids get rid of the evil eye. She would ask for something to eat and, why not, for a nice drink as well. By then she had taught me how to treat stomach ache with a ribbon, a healing skill which helped me earn something to put in the pot and buy books with drawings, but that day she did not allow me to join her.

The evening came cold, and mother was not back. The sluggard called out to me. He took a swig from the wine pitcher, grabbed a belt, and, as he wrapped it around his hand, said, "Don't cry, filthy boy; your mother got drunk or maybe she left with another man. If I'm right, she will never be back, and I don't want any nuisances in my way."

I turned my back as soon as I heard his words, held the wagon's wheel and waited for the whipping. He threw the whip to the ground.

"Remove your clothes", he said.

When he saw me naked, he came closer and touched me. He threw me to the floor and tied my hands to the wheel. I could feel him at my back, then he opened my legs and touched me again. He groped me and got mad, the same way some winos who fondled my mother by the fire pit once did. He put his hand in his fly, breathed on me, and made me bleed. Afterwards he untied me, climbed into the carriage and left. I wanted to run after him so he would admit that he lied about my mother, but my hips and legs were numbed, and I fell.

When I woke up, I had been blessed: my mother was hugging me.

"Don't worry, Petre, we are leaving." Once in the station, she said, "This train is going to change our luck; we will look for my father and we will be the happiest Gypsies on earth.”

Indeed, the journey made us happy and, hand in hand, my mother and I laughed when the train roared in the tunnels. My mother did not hug me often, but when she did, all sorrows left.

When we arrived in Roque Pérez, we started to look for you, grandpa.

"Hey," my mom would ask in the station, "don't you know an old Gypsy man who drives a red wagon? I am his daughter, and this is his grandson. We are looking for him."

For a long time, we walked from one village to another, just for the sake of walking.

Then, when I turned eleven, my mother wanted to give me away. She was going to get married again. I got angry, took her shoes, and threw them away. Then, I got the wedding dress she had made for herself and threw it to the floor. My mother picked it up and ordered me to leave. She told me to look for you on my own and grabbed a stick to hit me on my legs so I would run. "Lame, you will be lame. I will eat your legs away." Still, the whipping did not hurt until she said, "You already scared one away. You, premature boy." 
And it was then that I stabbed her with a knife.

Grandpa, I realize now that my mother drank only to forget. At times she would look at me between one drink and the next, shaking her head in disbelief, horrified by our misfortune.

As long as I can remember, the booze never let her grasp ideas clearly, so she would try to spank me or, just the opposite, she would treat me to a cigarette, and we'd drink and smoke together. During one of those early days when she let me drink with her, when my father was still alive, I saw her belly growing out of her skinny body. But she would look sadly at it, so I was not hopeful. That evening, in a rage, I told my father that the baby would be premature.

"Right," he said. "Now we have another fortune teller in the family."

That night I tossed around in bed, unable to sleep. My dad slid the blanket away, gently grabbed my hand and took me outside the wagon. We sat cross-legged on the grass. He calmly rolled a cigarette, lit it, and handed me the tobacco bag and a rolling paper.

He instructed as he used to. "Enjoy your cigarette, take your time, and even out the leaves as if they were words in a poem." Then he lay down with the cigarette in his mouth.

"What do you know about poems? You cannot read."

"I know what a poem is."

"And what is it?" I dared him.

He smiled and said, "A boy like you under the sky."

"Bah!" And I hugged him so I could feel his smell.

And what is it to be a Gypsy, grandpa?

Another poem, usually sad, occasionally happy. To be a Gypsy is to know our own ways and laws, which drive the life of the group. All Gypsies are alike, we can recognize each other by looking into the eyes. We are a fraternity, bonded by the same mandate: to be happy inside the hole and unhappy outside it. Maybe we should have been happy also outside. We stayed inside the hole for too long, and we were left outside the times. People hate us because we ruin their landscape, they avoid us, they don't want us in the schools or at the workplace; they lose their smile when they see us.

We are very good at surviving, but we don't give our children the opportunity to study. To despise the wisdom and knowledge in the books is to despise the world. We don't know what our rights are, and we don't know what the others' rights are either. All that is taught in school, but we don't want to go and they don't want us there anyway. But the price for not knowing our own rights is on us.

And why are we more sad than happy?

The old wise men, a bunch of elitists, classists, and racists, say that to be true Gypsies we must be free. We should not go to school, nor live, work, or think as the gadye do; that's why we have our traditions. Maybe in the future, Gypsies might get together somewhere and find an anthem and a flag. Gypsies need symbols that dignify our culture. Had I gone to school I would have done that. I would understand the world better, I think. 
What if I could understand, grandpa? I could help you out and we would be better Gypsies, and people wouldn't curse us when they see us, nor lose their smile when we look at them.

I don't think things would be much different, but with time life would be better for you, and for Tomás, Damián and Yuri, for Veruska, for Natasha, for Voria, for Voria Rosa, and for the eight, ten, or twelve million Gypsies who I carry every day in my wagon.

My father used to smoke under the stars. He used to say that we should never lose connection with whatever is up there. The earth gets what it needs from there, and it is there where men find the answers they are looking for.

I did not quite understand dad when he said those things, but his face was confident and hopeful. So I asked him, "Does it say up there what would be of my little brother if he is born premature?"

"What a tongue you have, worse than your mother!" he said.

"Maybe, but you did not answer my question."

"How do you want me to answer you if I cannot read?"

"Dad," I asked him, "Do we take care of poems?"

"Of course, no doubt about it."

"Well," I warned him, "Don't you doubt it either when my brother is born."

Fifteen days after she gave birth, my mother's breasts went dry. She cried in despair for the little girl who, like me, was born premature. My father asked my mother to offer her the breast, but she wouldn't. The day she was born my dad and I cried; we had prayed for a full-term boy who would eventually take care of things when my father, in his rushed old-age, could not.

But God wouldn't help us, and my mother did not take long in leaving the little girl aside to return to the booze. Between one drink and the next she would look up to the sky, then to the girl, and, finally, to me, shaking her head slowly. I knew that we had done something terrible for God to punish us a second time.

One evening, my mother prepared a bottle, placed it in the baby's mouth, and fixed it with a cloth wrapped around her neck. Instead of holding it, the cloth pushed the bottle in. It went so deep that the baby could not even cry. When we found her, she was still, face up, the color of a sugar beet. It took me some time to untie the knot. While my dad filled a water bowl, I undressed her. Little angels must be clean when they arrive in heaven. My hands were trembling in sorrow.

When we finished bathing her, we dried her and wrapped her with a blanket, then we put her in a basket. Carefully, I placed it under a tree, away from the ants and sun. Later, we went to where my mother was lying. She had so much alcohol in her body that the sun might have lit her had a tree not covered her with its shadow. It took effort to place her leaning back on the tree. She was unconscious and her body slid away like an eel. I thought that it would have been easy to place a bottle in her boozer's open mouth, tie it up with a cloth, and wait for time to work it out, but my father's voice sounded right there as a warning.

"Don't you think about it now, we have to bury your sister."

He said nothing else. We left my mother and walked towards the tree where we had left the basket protecting the baby from the ants. But it was nowhere to be seen. Not far, Mr. Patarino's wild pigs were 
fighting, the baby's body flying around between them. We ran and yelled, and some pigs rushed away, but not the biggest three. They stood their ground, waiting for a fight. When they realized what we wanted they charged, and we fought them back with sticks. One of the pigs went back, got the remains of the little girl, and joined the rest of the herd. Dad and I could not retrieve a single piece.

This new misfortune took away all my strength and the desire to take revenge on my mother. When she woke up from her stupor, she refused to believe the story of the bottle. She found the trace of blood and the rags that the pigs left behind, and she took out her rage on us. First, she screamed, then she took a thumb-thick wire and hit us as much as she could. Days later, she would still be seized by random madness and we got the worst of her anger if we were asleep or distracted.

We did all the chores in the wagon so she would tolerate our presence. We cooked when we had something, we cleaned the wagon, and my dad groomed and fed the mule. Oddly enough, my dad would be happy only around the animal; he loved me, true enough, but he also worried about me. Sometimes, when I wasn't looking at him, he would set his eyes on me, and I could feel his soul in his gaze. He saw no future for me.

My father harnessed the mule to the wagon and headed to Mr. Patarino's house.

My mother carelessly said, "Nature is wise. With this miserable life we have, what were we supposed to do with two premature children?"

Dad thought about it, and found wisdom, or maybe relief, in what my mother had said. He hit the whip on the animal's hindquarters and turned around violently. The mule, taken by surprise, was forced to exit the road in order to turn. She stepped in a burrow and broke her leg. My dad would remember the wood-like cracking sound of the bone as it broke. It was difficult for him to load the shotgun and look into the mule's eyes. He said that the shot was like thunder on the heart of his soul. From then on, my dad let himself die.

My father loved trucks and he wanted to drive one the way the rich Gypsies did, but he could not afford it, not even an old one. He was on his own with the wagon, but he still loved his dead mule. Without her and with all the sorrow we carried, our life became very hard. We would be without work for long periods, with no chance of getting another mule. My mother was wasted, my father was sick, especially after she hit him with the wire.

It makes no sense, grandpa, to keep going on remembering. My dad was slowly dying with every passing evening, and one day he died all together. After that, the wino came with all his filth. Sometimes I got confused and drank, not much, just a little, so I would imagine you standing on your wagon, looking for me among the people, and the hope of seeing you again would grow in me. And life would be filled with laughter.

Grandpa, I can promise you that when I have children they will go to school, and they will see the Gypsy flag waving, and they will sing our anthem. Our wisdom does not need the knowledge in the books to embrace us all, making us equal in the world, being better Gypsies every day that goes by. 